AGRITECH, Vol. 37, No. 4, November 2017, Hal. 428-436

DOI: http://doi.org/10.22146/agritech.22963

ISSN 0216-0455 (Print), ISSN 2527-3825 (Online)

Tersedia online di https://jurnal.ugm.ac.id/agritech/

\title{
Pengaruh Penambahan Asam Galat Sebagai Kopigmen Antosianin Murbei Hitam (Morus nigra L.) terhadap Stabilitas Termal
}

\author{
Effect Addition of Gallic Acid as Copigment for Black Mulberry Anthocyanin (Morus nigra L.) Towards Thermal Stability \\ Yoko Putra Nusantara, Lydia Ninan Lestario*, Yohanes Martono
}

\author{
Program Studi Kimia, Fakultas Sains dan Matematika, Universitas Kristen Satya Wacana, \\ J1. Diponegoro 52-60, Salatiga 50711, Indonesia \\ Email: nlestario@gmail.com
}

Submisi: 13 Maret 2017; Penerimaan: 18 Agustus 2017

\begin{abstract}
ABSTRAK
Tujuan penelitian ini adalah untuk menentukan efek kopigmentasi antosianin murbei dengan asam galat terhadap panas dan menentukan rasio molar antosianin: asam galat yang optimal untuk menstabilkan antosianin murbei. Variasi perlakuan penelitian ini adalah rasio molar antosianin: asam galat: 1:0; 1:25; 1:50; 1:75; 1:100 yang dipanaskan pada suhu $60^{\circ} \mathrm{C}, 70{ }^{\circ} \mathrm{C}, 80^{\circ} \mathrm{C}$, dan $90^{\circ} \mathrm{C}$. Setelah pemanasan selesai, dilakukan pengukuran intensitas warna setiap 45 menit pada suhu $60{ }^{\circ} \mathrm{C}$, 30 menit pada suhu $70^{\circ} \mathrm{C}, 30$ menit pada suhu $80{ }^{\circ} \mathrm{C}$, dan 20 menit pada suhu $90{ }^{\circ} \mathrm{C}$. Pengukuran dilakukan pada panjang gelombang $512 \mathrm{~nm}$ pada antosianin yang tidak terkopigmentasi dan $514 \mathrm{~nm}$ pada antosianin yang terkopigmentasi dengan menggunakan Spektrofotometer UV-VIS. Hasil penelitian menunjukkan bahwa kopigmentasi meningkatkan stabilitas antosianin murbei terhadap panas. Kopigmentasi dapat meningkatkan energi aktivasi dan waktu paruh. Rasio molar optimal antosianin:asam galat adalah 1:75 dengan energi aktivasi sebesar $65,20 \mathrm{~kJ} / \mathrm{mol}$.
\end{abstract}

Kata kunci: Antosianin; kopigmentasi; asam galat; murbei; stabilitas

\begin{abstract}
The purposes of this research were to determine the effect of copigmentation of mulberry anthocyanin with gallic acid towards thermal and to determine the optimal molar ratio of anthocyanin: gallic acid to stabilize the mulberry anthocyanin. The variation of treatments on this research were molar ratio of mulbery anthocyanin: gallic acid: 1:0; 1:25; 1:50; 1:75; $1: 100$ which were heated at $60{ }^{\circ} \mathrm{C}, 70{ }^{\circ} \mathrm{C}, 80{ }^{\circ} \mathrm{C}$, and $90{ }^{\circ} \mathrm{C}$. After heated, the colour intensity were measured every 45 minutes at $60{ }^{\circ} \mathrm{C}, 30$ minutes at $70{ }^{\circ} \mathrm{C}, 30$ minutes at $80{ }^{\circ} \mathrm{C}$, and 20 minutes at $90{ }^{\circ} \mathrm{C}$. The measurement was conducted on wavelength $512 \mathrm{~nm}$ for uncopigmented anthocyanin and $514 \mathrm{~nm}$ for copigmented anthocyanin using Spectrophotometer UV-VIS. The result showed that copigmentation could increase the thermal stability of mulberry anthocyanin. Copigmentation could increase the activation energy and half life. The optimal molar ratio of anthocyanin: copigment was 1:75, while the energy of activation was $65.20 \mathrm{~kJ} / \mathrm{mole}$.
\end{abstract}

Keywords: Anthocyanin; copigmentation; gallic acid; mulberry; stability 


\section{PENDAHULUAN}

Salah satu parameter yang sering digunakan untuk menentukan mutu suatu makanan adalah warna (Winarno, 1997). Meskipun suatu pangan memiliki gizi yang baik akan tetapi jika warnanya kurang menarik dapat membuat konsumen tidak mau mengkonsumsi pangan tersebut. Sehingga warna memiliki peranan yang sangat penting dalam pangan. Akhir-akhir ini terjadi peningkatan penggunaan pewarna sintetik. Peningkatan tersebut disebabkan oleh harga yang lebih murah dan sifat lebih stabil terhadap pemanasan (Nugraheni, 2014). Walaupun memiliki kelebihan, beberapa pewarna sintetik berbahaya bagi kesehatan tubuh. Pewarna sintetik dapat meningkatkan enzim aminotransferase yang membahayakan organ ginjal, liver, dan jantung. Selain itu dapat meningkatkan ALT, AST, dan alkaline phospatase yang dapat membahayakan sel liver (Amin dkk., 2010). Sehingga perlu dicari pewarna alternatif untuk bahan pangan. Salah satu pewarna alternatif pangan yang dapat digunakan adalah antosianin. Antosianin merupakan senyawa turunan flavonoid yang berwarna merah-ungu (He dan Giusti, 2010). Antosianin dapat diperoleh buah yang berwarna ungu, salah satunya adalah buah murbei. Kandungan antosianin dalam buah murbei sebanyak 30,8 - 83 mg/100 g (Özgen dkk., 2009). Antosianin bukan hanya menjadi pewarna, akan tetapi memiliki efek yang baik bagi kesehatan tubuh manusia (He dan Giusti, 2010).

Penggunaan antosianin sebagai pewarna dibatasi dengan sifatnya yang kurang stabil terhadap oksigen, cahaya, $\mathrm{pH}$, gula, dan suhu (Kokkaew dan Pitirit, 2016). Sehingga perlu dilakukan upaya untuk meningkatkan stabilitasnya. Salah satu upaya untuk meningkatkan stabilitasnya dengan cara kopigmentasi (Sari, 2015). Kopigmentasi dapat meningkatkan stabilitas antosianin dengan cara senyawa kopigmen membentuk ikatan kompleks dengan antosianin, sehingga dapat mengurangi interaksi antosianin dengan molekul air. Interaksi antosianin dengan molekul air menyebabkan antosianin mengalami degradasi (González-Manzano dkk., 2009). Selain itu, kopigmentasi dipengaruhi oleh beberapa senyawa kofaktor seperti senyawa asam fenolik, flavonoid, asam amino, alkaloid, dan interaksi antar-molekul antosianin (Bimpilas dkk., 2016).

Beberapa penelitian tentang kopigmentasi buah murbei antara lain kopigmentasi dengan asam tanat (Ramadan dan ElHadidy, 2015), kopigmentasi dengan asam p-hidroksi benzoat, asam klorogenat, dan kuersetin 3-O- $\beta$-D-glucopiranosida yang diisolasi dari buah murbei (Bang dkk., 2010), kopigmentasi dengan beberapa asam organik yaitu asam tanat, kumarat, benzoat, dan kafeat (Hajizadeh dan Jamei, 2015). Sejauh ini penelitian tentang kopigmentasi buah murbei dengan asam galat belum dilakukan, sehingga pada penelitian ini akan dikaji tentang penggunaan asam galat sebagai kopigmen buah murbei. Hasil penelitian menunjukkan asam galat dapat meningkatkan waktu paruh antosianin dibandingkan dengan tanpa penambahan kopigmen (Kopjar dan Pilizota, 2009); Gauche dkk., 2010); Sari, 2015). Hasil penelitian Kopjar dan Piližota (2009) menunjukan bahwa asam galat dengan rasio molar 1:100 dapat meningkatkan waktu paruh antosianin buah Red Currant (323,5 hari) dibandingkan tanpa kopigmen (136,3 hari). Jika dibandingkan dengan kopigmen lain pada rasio molar yang sama seperti katekol (212,1 hari), 4-metil katekol (168,7 hari), dan katekin (249,9 hari) maka asam galat meningkatkan waktu paruh antosianin Red Currant paling tinggi. Selain itu pada penelitan ini digunakan pelarut asam tartarat. Hasil penelitian Tensiska dkk. (2007) dan Lestario dkk. (2014) menunjukkan bahwa asam tartarat dapat mengekstrak antosianin lebih optimal dibandingkan dengan asam sitrat dan asam asetat. Berdasarkan permasalahan diatas, tujuan penelitian ini adalah mengetahui ada atau tidaknya pengaruh kopigmentasi dengan asam galat terhadap stabilitas termal antosianin buah murbei dan menentukan konsentrasi kopigmen optimal untuk meningkatkan stabilitas termal antosianin murbei.

\section{METODE PENELITIAN}

\section{Bahan}

Sampel buah murbei dipetik dari pohon yang tumbuh di Salatiga. Reagen yang digunakan dalam penelitian ini meliputi : metanol, $\mathrm{HCl}, \mathrm{KCl}$, asam tartarat, natrium sitrat, asam sitrat dengan tingkat kemurnian 99\% (Merck, Jerman). Selain itu digunakan asam galat dengan kemurnian 99\% (Sigma Aldrich, St Louis MO), etanol teknis dengan kemurnian 96\%.

\section{Alat}

Peralatan yang digunakan dalam penelitian ini meliputi : moisture balance (OHAUS MB45), freeze dryer (Thermoscientific Heto Power Dry LL 1500), timbangan analitik 4 desimal (tingkat ketelitian 0,1 mg) (OHAUS PA214), spektrofotometer UV-VIS (Shimadzu 1240), waterbath (Memmert), orbital shaker (IKA KS 501).

\section{Pengeringan Buah Murbei dengan Pengeringan Beku}

Sebelum dikeringkan dengan pengeringan beku dilakukan pengukuran kadar air buah murbei dengan moisture balance. Pengeringan beku dilakukan selama 36 jam dengan alat freeze dryer. Setelah proses pengeringan beku, sampel murbei digrinder lalu disimpan pada suhu $-4{ }^{\circ} \mathrm{C}$.

\section{Pengukuran Antosianin Total Buah Murbei (Lestario dkk., 2014)}

Sejumlah $1 \mathrm{~g}$ sampel murbei hasil pengeringan beku diekstrak dengan dengan $30 \mathrm{~mL}$ larutan dengan metanol - 1\% 
$\mathrm{HCl}$ selama 1 malam pada suhu $-4{ }^{\circ} \mathrm{C}$, kemudian disaring untuk memisahkan filtrat dari ampasnya, filtrat dimasukkan ke dalam labu takar $100 \mathrm{~mL}$. Setelah itu residu diekstrak kembali 3 kali $20 \mathrm{~mL}$ dengan pelarut yang sama menggunakan orbital shaker selama 20 menit. Filtrat disaring dan ditampung bersama hasil maserasi pertama. Labu takar digenapkan sampai garis tera dengan pelarut yang sama. Sebanyak $0,1 \mathrm{~mL}$ ekstrak dimasukkan dalam 2 buah tabung reaksi, kemudian masing-masing tabung diberi buffer $\mathrm{pH} 1$ dan buffer $\mathrm{pH}$ 4,5 sebanyak 3,9 mL. Kedua tabung didiamkan selama 15 menit lalu absorbansnya diukur pada panjang gelombang $510 \mathrm{~nm}$ dan $700 \mathrm{~nm}$ dengan spektrofotometer UV-VIS. Absorbansi sampel diukur dengan sesuai dengan Persamaan 1:

$A=\left(A_{510}-A_{700}\right)_{p H 1}-\left(A_{510}-A_{700}\right)_{p H 4,5}$

Hasil perhitungan menggunakan hukum Lambert Beer

$A=\varepsilon l c$

Keterangan:

$A=$ absorban sampel

$\varepsilon=$ koefisien ekstingsi molar sianidin 3-glikosida $=29.600 \mathrm{~L} \mathrm{~mol}^{-1} \mathrm{~cm}^{-1}$

$l=$ lebar kuvet $(\mathrm{cm})$

$c=$ konsentrasi $(\mathrm{mol} / \mathrm{L})$

Konsentrasi antosianin dihitung dengan koefisien ekstingsi molar $29.600 \mathrm{~L} \mathrm{~mol}^{-1} \mathrm{~cm}^{-1}$, dan berat molekul sianidin 3-glikosida 445,2 g/mol.

Optimasi Pelarut Asam Tartarat (Tensiska dkk., 2007, yang dimodifikasi)

Sejumlah 0,5 g sampel murbei hasil pengerinngan beku diekstrak dengan dengan $30 \mathrm{~mL}$ larutan asam tartarat (b/v) $0,5 \%, 1 \%, 1,5 \%, 2 \%, 3 \%, 4 \%$, dan 5\% selama 1 malam dalam suhu $-4{ }^{\circ} \mathrm{C}$, lalu disaring dan filtratnya dimasukkan ke dalam labu takar $50 \mathrm{~mL}$. Setelah itu residu diekstrak kembali 2 kali $10 \mathrm{~mL}$ dengan pelarut yang sama menggunakan orbital shaker selama 20 menit. Filtrat disaring dan ditampung bersama hasil maserasi pertama. Labu takar digenapkan sampai garis tera dengan pelarut yang sama. Pengukuran antosianin terekstrak dilakukan dengan metode perbedaan $\mathrm{pH}$ (Lestario dkk., 2014).

\section{Kopigmentasi dengan Variasi Konsentrasi Kopigmen dan Suhu (Sari, 2015; Zoric dkk., 2014 yang Dimodifikasi)}

Konsentrasi asam tartarat yang optimal dari hasil penelitian adalah $2 \%$. Sejumlah 1 , g sampel hasil pengeringan beku dimaserasi dengan $30 \mathrm{~mL}$ asam tartarat $2 \%$ selama 1 malam dalam suhu dingin, lalu disaring dengan menampung filtratnya ke dalam labu takar $100 \mathrm{~mL}$. Setelah itu residu diekstrak kembali 2 kali sebanyak $25 \mathrm{~mL}$ dan $20 \mathrm{~mL}$ pelarut yang sama menggunakan orbital shaker selama 20 menit. Filtrat disaring dan ditampung bersama hasil maserasi pertama. Labu takar digenapkan sampai garis tera dengan pelarut yang sama. Antosianin total dihitung dengan metode perbedaan pH (Lestario dkk., 2014). Ekstrak tersebut digunakan untuk proses kopigmentasi.

Asam galat ditimbang sebanyak 25, 50, 75, dan 100 kali jumlah molnya dibandingkan dengan mol 1,5 mL ekstrak pekat antosianin sehingga rasio molar antosiani:kopigmen menjadi 1:0, 1:25, 1:50, 1:75, 1:100. Asam galat dilarutkan dengan $2 \mathrm{~mL}$ etanol dan 6,5 mL akuades. Sebanyak 1,5 mL ekstrak pekat antosianin dalam asam tartarat $2 \%$ dipipetkan ke dalam larutan asam galat lalu larutan diberi $20 \mathrm{~mL}$ asam tartarat 2\%. Ekstrak dihomogenkan dengan orbital shaker selama 20 menit. Larutan homogen dipipet dan dimasukkan ke dalam tabung reaksi masing-masing $5 \mathrm{~mL}$. Ekstrak yang tidak terkopigmentasi maupun terkopigmentasi (1:100) dipindai pada panjang gelombang 200-700 nm sehingga diperoleh panjang gelombang maksimal. Setelah dikopigmentasi ekstrak antosianin dimasukkan ke dalam waterbath suhu 60 ${ }^{\circ} \mathrm{C}, 70{ }^{\circ} \mathrm{C}, 80{ }^{\circ} \mathrm{C}$, serta $90{ }^{\circ} \mathrm{C}$. Diukur absorbansi antosianin pada masing-masing suhu pada waktu $0,45,90,135,180$, dan 225 menit untuk suhu $60^{\circ} \mathrm{C}$ dan $0,30,60,90,120,150$ menit untuk suhu $70{ }^{\circ} \mathrm{C}$ dan $80{ }^{\circ} \mathrm{C}$. Sedangkan pada suhu $90{ }^{\circ} \mathrm{C}$ diukur pada waktu $0,20,40,60,80,100$ menit. Pengukuran dilakukan pada panjang gelombang $(\lambda)$ maksimal hasil pengukuran yaitu 512 untuk tidak terkopigmentasi dan 514 untuk yang terkopigmentasi.

\section{Analisa Data (Atkins and Paula, 2008)}

Data retensi warna diplotkan dalam kurva orde reaksi untuk menentukan orde reaksi, nilai konstanta laju degradasi antosianin dan nilai waktu paruh. Data konstanta laju reaksi degradasi antosianin dan suhu diplotkan dengan kurva Arrhenius sehingga diperoleh nilai energi aktivasi.

$\ln \frac{K 2}{K 1}=\frac{-E a}{R}\left(\frac{1}{T 2}-\frac{1}{T 1}\right)$

\section{HASIL DAN PEMBAHASAN}

\section{Antosianin Total}

Hasil penelitian menunjukkan kadar antosianin total dengan pelarut metanol - $1 \% \mathrm{HCl}$ sebesar $435 \mathrm{mg} / 100 \mathrm{~g}$ berat segar. Beberapa penelitian sebelumnya melaporkan bahwa kandungan antosianin dalam buah murbei sebesar 30,8 - 83,0 mg/100 g (Özgen dkk., 2009), 223 mg/100 g (Kara dan Er elebi, 2013). Dibandingkan dengan penelitian sebelumnya, kadar antosianin total pada buah murbei hasil penelitian ini lebih besar. Perbedaan tersebut disebabkan oleh 
Tabel 1. Pengukuran antosianin total pada buah segar dan buah setelah proses pengeringan beku

\begin{tabular}{lc}
\hline \multicolumn{1}{c}{ Jenis Perlakuan } & $\begin{array}{c}\text { Antosianin total } \\
(\mathrm{mg} / 100 \mathrm{~g})(\dot{X} \pm S E)\end{array}$ \\
\hline Buah segar & $434,67 \pm 6,75$ \\
Buah kering beku & $2744,64 \pm 42,84$ \\
Buah kering beku (tanpa air) & $3177,41 \pm 49,60$ \\
\hline
\end{tabular}

\section{Keterangan:}

* Buah kering beku merupakan buah murbei hasil proses pengeringan beku yang masih memiliki kadar air.

* Buah kering beku (tanpa air) merupakan buah murbei hasil pengeringan beku dikurangi kadar air buah hasil pengeringan beku.

* Hasil 3 ulangan pengukuran.

perbedaan varietas, tempat penanaman, musim pada sampel buah murbei yang digunakan. Özgen dkk. (2009) melaporkan bahwa perbedaan varietas buah murbei menyebabkan perbedaan kadar antosianin total pada buah murbei yang ditanam di negara Turki.

\section{Optimasi Pelarut Asam Tartarat}

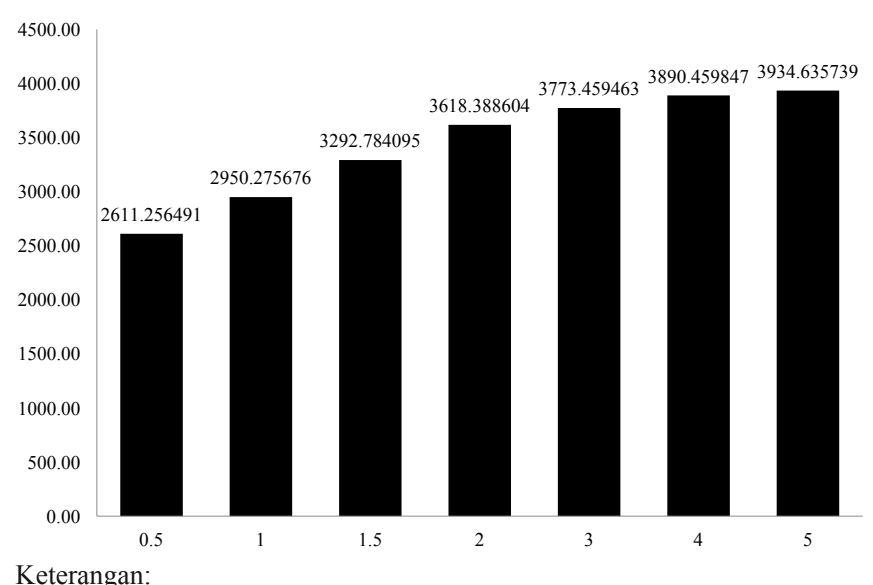

* Uji statistik dilakukan dengan BNJ (Beda Nyata Jujur) 5\% dengan nilai W $=94,70$

* Angka-angka yang diikuti oleh huruf yang sama menunjukkan tidak ada beda nyata antar perlakuan. Sebaliknya angka-angka yang diikuti oleh huruf yang tidak sama, menunjukkan tidak ada beda nyata antar perlakuan.

* Hasil merupakan rerata dari 3 kali pengulangan (triplo).

Gambar 1. Grafik antosianin murbei yang terekstrak dengan variasi konsentrasi pelarut asam tartarat dalam berat kering

Berdasarkan hasil uji statistik, hasil penelitian menunjukkan jumlah antosianin yang optimal pada saat konsentrasi pelarut asam tartarat 1,5\%, karena tidak berbeda nyata dengan konsentrasi 2-5\%. Namun jika dilihat dari kenaikan antosianin yang terlarut, pada saat konsentrasi asam tartarat $0,5-2 \%$ terjadi kenaikan yang besar (300-400 mg/100 g buah) kemudian pada konsentrasi 3-5\% kenaikan antosianin terekstrak lebih sedikit. Ekstraksi antosianin pelarut asam tartarat 3-5\% tidak efisien karena kenaikannya hanya sedikit, sehingga konsentrasi yang dipilih adalah 2\% (Gambar 1). Berdasarkan hasil tersebut dapat disimpulkan bahwa konsentrasi asam tartarat yang efisien untuk mengekstrak antosianin murbei adalah $2 \%$. Peningkatan jumlah antosianin terekstrak disebabkan oleh peningkatan jumlah ion $\mathrm{H}^{+}$yang meningkat menurunkan $\mathrm{pH}$ larutan mendekati 1, sesuai dengan $\mathrm{pH}$ optimal antosianin yaitu pH 1 (Fennema, 1996). Selain itu peningkatan jumlah asam tartarat menyebabkan peningkatan jumlah ion tartarat yang mampu mengkelat (menarik) antosianin, sehingga antosianin yang terekstrak meningkat (Tensiska dkk., 2007; Hosseini dkk., 2016).

Hasil penelitian juga menunjukkan bahwa antosianin terekstrak dengan pelarut metanol $-1 \% \mathrm{HCl}$ (Tabel 1) lebih kecil dibandingkan dengan asam tartarat 1,5\% (b/v) (Gambar 1) dan asam tartarat dengan konsentrasi yang lebih tinggi. Hasil tersebut disebabkan oleh sifat asam organik seperti asam tartarat yang mampu mengkelat antosianin sehingga antosianin lebih banyak terekstrak. Kemampuan mengkelat menyebabkan terjadinya interaksi tarik-menarik asam tartarat dengan antosianin. Bahkan kemampuan mengkelat asam tartarat lebih baik dibandingkan dengan asam sitrat. Sedangkan $\mathrm{HCl}$ tidak mampu mengkelat atau berinteraksi dengan antosianin, $\mathrm{HCl}$ menghidrolisis dinding sel saat ekstraksi dan memberikan suasana asam pada antosianin (Tensiska dkk., 2007; Hosseini dkk., 2016).

\section{Pengaruh Kopigmentasi terhadap Pergeseran Panjang Gelombang Maksimum}

Hasil penelitian menunjukkan terjadinya pergeseran batokromik sebesar $2 \mathrm{~nm}$ dan tidak terjadi pergeseran hiperkromik (Tabel 2). Kopigmentasi antosianin dengan asam organik akan memberikan efek pergeseran batokromik dan hiperkromik (Boulton, 2001). Pergeseran batokromik yang terjadi sesuai dengan hasil penelitian Eiro and Heinonen (2002) yang melaporkan bahwa kopigmentasi antosianin murni Sianidin 3-glukosida dengan asam galat (rasio molar 1:100) memberikan efek batokromik yang lebih kecil $(5,3$ $\mathrm{nm}$ ) dibandingkan dengan asam organik lain seperti asam ferulat $(12,3 \mathrm{~nm})$, asam kafeat $(10,2 \mathrm{~nm})$, asam rosmarinic (15,2 nm), asam klorgenat (10,4 nm). Sedangkan Sari (2015) melaporkan bahwa tidak terjadi pergeseran batokromik pada kopigmentasi antosianin buah Berberis crataegina dengan asam galat. Menurut Eiro and Heinonen (2002) struktur antosianin yang dikopigmentasi mempengaruhi efek batokromik yang dihasilkan. Antosianin yang mengikat satu gula (monosakarida) akan menghasilkan efek batokromik yang lebih besar dibandingkan dengan antosianin yang mengikat tiga gula (trisakarida) maupun antosianin yang terasilasi dengan asam organik. Antosianin buah murbei mengandung jenis antosianin : Sianidin 3-glukosida 
Tabel 2. Efek kopigmentasi terhadap panjang gelombang maksimal antosianin murbei pada rasio molar antosianin:kopigmen 1:100 dibandingkan dengan kontrol (1:0)

\begin{tabular}{cc}
\hline Antosianin:asam galat & $\begin{array}{c}\text { Panjang gelombang maksimum } \\
(\mathrm{nm})\end{array}$ \\
\hline $1: 0$ & 512 \\
$1: 100$ & 514 \\
\hline
\end{tabular}

Keterangan:

*Hasil 3 ulangan percobaan

(64,13\%), Sianidin 3-rutinosida (35,21\%), Pelargonidin 3-glukosida (0,66\%), (Stefănut dkk., 2011). Antosianin pada buah murbei sebagian besar merupakan jenis antosianin monosakarida. Hal tersebut memungkinkan terjadinya pergeseran batokromik pada antosianin murbei yang terkopigmentasi asam galat. Sedangkan pada buah Berberis crataegina diduga mengandung banyak antosianin trisakarida dan antosianin terasilasi asam organik, sehingga tidak menyebabkan pergeseran batokromik saat dikopigmentasi dengan asam galat.

Interaksi yang terjadi adalah pembentukan senyawa kompleks dengan mekanisme interaksi transfer elektron bebas atom Oksigen pada gugus fenol atau karboksilat pada asam galat dengan molekul antosianin. Interaksi antosianin dengan kopigmen menyebabkan tumpang tindih pada orbital elektron . Interaksi tumpang tindih orbital menyebabkan sifat hidrofobik pada antosianin buah murbei, sehingga antosianin lebih stabil terhadap reaksi degradasi akibat interaksi dengan air. Interaksi secara kimiawi digambarkan seperti sandwich, terjadi saling tumpang tindih molekul antosianin dan Asam Galat (Ferreira da Silva dkk., 2005; Trouillas dkk., 2016).

\section{Penentuan Orde Reaksi}

Orde reaksi ditentukan berdasarkan nilai $\mathrm{R}^{2}$ yang paling besar. Semakin besar nilai $\mathrm{R}^{2}$ maka semakin cocok dengan model orde tersebut. Hasil penelitian ini menunjukkan pada suhu $60{ }^{\circ} \mathrm{C}, 70{ }^{\circ} \mathrm{C}$, dan $80{ }^{\circ} \mathrm{C}$ semua rasio molar antosianin:kopigmen mengikuti orde reaksi 2. Sedangkan pada suhu $90{ }^{\circ} \mathrm{C}$ pada rasio molar antosianin:kopigmen 1:0 dan 1:50 mengikuti orde reaksi 1 sedangkan pada rasio molar antosianin : kopigmen 1:25, 1:75, 1:100 mengikuti orde reaksi 2 (Tabel 2). Namun perbedaan nilai $\mathrm{R}^{2}$ antara orde 1 dan orde 2 pada pada kopigmen 1:0 dan 1:50 (0,0010 dan 0,0013) tidak sebesar seperti suhu $60^{\circ} \mathrm{C}, 70^{\circ} \mathrm{C}$, dan $80^{\circ} \mathrm{C}(0,0020-0,0091)$ sehingga reaksi dianggap memenuhi orde reaksi 2. Hasil penelitian ini tidak sama dengan penelitian yang dilakukan oleh Suh dkk. (2003) dan Boranbayeva dkk. (2014). Suh dkk. (2003) melaporkan bahwa reaksi degradasi antosianin murbei mengikuti orde reaksi 0, sedangkan Boranbayeva dkk. (2014)
Tabel 3. Nilai $\mathrm{R}^{2}$ dari data retensi degradasi antosianin buah murbei pada berbagai suhu dan variasi rasio molar yang diplotkan pada orde reaksi 0,1 , dan 2 .

\begin{tabular}{|c|c|c|c|}
\hline \multicolumn{4}{|c|}{ Suhu $60^{\circ} \mathrm{C}$} \\
\hline Antosianin : Kopigmen & $\mathrm{R}^{2}$ orde 0 & $\mathrm{R}^{2}$ orde 1 & $\mathrm{R}^{2}$ orde 2 \\
\hline $1: 0$ & 0,8993 & 0,9059 & 0,9119 \\
\hline $1: 25$ & 0,9451 & 0,9503 & 0,9551 \\
\hline $1: 50$ & 0,9556 & 0,9592 & 0,9626 \\
\hline $1: 75$ & 0,9642 & 0,9667 & 0,9688 \\
\hline $1: 100$ & 0,9482 & 0,9518 & 0,9552 \\
\hline \multicolumn{4}{|c|}{ Suhu $70^{\circ} \mathrm{C}$} \\
\hline Antosianin : Kopigmen & $\mathrm{R}^{2}$ orde 0 & $\mathrm{R}^{2}$ orde 1 & $\mathrm{R}^{2}$ orde 2 \\
\hline $1: 0$ & 0,9180 & 0,9277 & 0,9368 \\
\hline $1: 25$ & 0,9530 & 0,9578 & 0,9619 \\
\hline $1: 50$ & 0,9787 & 0,9819 & 0,9846 \\
\hline $1: 75$ & 0,9436 & 0,9491 & 0,9541 \\
\hline $1: 100$ & 0,9338 & 0,9399 & 0,9457 \\
\hline \multicolumn{4}{|c|}{ Suhu $80^{\circ} \mathrm{C}$} \\
\hline Antosianin : Kopigmen & $\mathrm{R}^{2}$ orde 0 & $\mathrm{R}^{2}$ orde 1 & $\mathrm{R}^{2}$ orde 2 \\
\hline $1: 0$ & 0,9339 & 0,9447 & 0,9545 \\
\hline $1: 25$ & 0,9367 & 0,9464 & 0,9552 \\
\hline $1: 50$ & 0,9666 & 0,9734 & 0,9792 \\
\hline $1: 75$ & 0.9767 & 0,9820 & 0,9865 \\
\hline $1: 100$ & 0,9683 & 0,9745 & 0,9798 \\
\hline \multicolumn{4}{|c|}{ Suhu $90^{\circ} \mathrm{C}$} \\
\hline Antosianin : Kopigmen & $\mathrm{R}^{2}$ orde 0 & $\mathrm{R}^{2}$ orde 1 & $\mathrm{R}^{2}$ orde 2 \\
\hline $1: 0$ & 0,9912 & 0,9933 & 0,9923 \\
\hline $1: 25$ & 0,9857 & 0,9916 & 0,9953 \\
\hline $1: 50$ & 0,9967 & 0,9980 & 0,9967 \\
\hline $1: 75$ & 0,9878 & 0,9925 & 0,9950 \\
\hline $1: 100$ & 0,9818 & 0,9860 & 0,9880 \\
\hline
\end{tabular}

Keterangan:

*Hasil dari 3 ulangan percobaan

melaporkan bahwa degradasi antosianin jus buah murbei dan ekstrak pekat murbei mengikuti orde reaksi 1 . Hal tersebut menunjukkan perbedaan sampel murbei mengikuti laju degradasi dengan orde reaksi yang berbeda. Pada penelitian ini sampel yang digunakan berbeda varietasnya dan pada tempat penanamannya, sehingga orde reaksinya pun berbeda.

\section{Pengaruh Kopigmentasi terhadap Stabilitas Termal Antosianin Murbei}

Secara umum penambahan kopigmen asam galat dapat menstabilkan antosianin pada buah murbei. Konsentrasi optimal kopigmen tiap suhu ditentukan berdasarkan nilai laju degradasi antosianin (k) dan waktu paruh. Semakin kecil nilai 
Tabel 4. Parameter kinetika termal degradasi antosianin murbei pada berbagai rasio molar antosianin:asam galat dan suhu mengikuti orde reaksi 2 ( $\mathrm{n}=3$ ulangan percobaan)

\begin{tabular}{|c|c|c|c|c|c|}
\hline $\begin{array}{l}\text { Antosianin : Asam } \\
\text { Galat }\end{array}$ & $\begin{array}{l}\text { Suhu } \\
\left({ }^{\circ} \mathrm{C}\right)\end{array}$ & $\begin{array}{c}\text { Konstanta reaksi } \\
\left.\text { (retensi }^{-1} \cdot \text { menit }^{-1}\right) \\
(X \dot{X} \pm S E\end{array}$ & $\begin{array}{c}\mathrm{t}_{1 / 2} \\
(\mathrm{jam})\end{array}$ & $\begin{array}{c}\text { Energi } \\
\text { aktivasi } \\
(\mathrm{kJ} / \mathrm{mol}) \\
\end{array}$ & $\begin{array}{l}\mathrm{R}^{2} \text { Kurva } \\
\text { Arrhenius }\end{array}$ \\
\hline \multirow{6}{*}{$1: 0$} & 60 & $(4,61 \pm 0,91) \times 10^{-4}$ & 36,47 & \multirow{6}{*}{54,88} & \multirow{6}{*}{0,9632} \\
\hline & 70 & $(7,75 \pm 0,31) \times 10^{-4}$ & 21,47 & & \\
\hline & 80 & $(10,96 \pm 0,93) \times 10^{-4}$ & 15,15 & & \\
\hline & 90 & $(25,38 \pm 1,88) \times 10^{-4}$ & 6,59 & & \\
\hline & $25 *$ & $4,21 \times 10^{-5}$ & 395,72 & & \\
\hline & $4 *$ & $7,85 \times 10^{-6}$ & 2122,24 & & \\
\hline \multirow{6}{*}{$1: 25$} & 60 & $(3,78 \pm 0,66) \times 10^{-4}$ & 44,33 & \multirow{6}{*}{56,74} & \multirow{6}{*}{0,9554} \\
\hline & 70 & $(7,44 \pm 1,12) \times 10^{-4}$ & 22,52 & & \\
\hline & 80 & $(9,49 \pm 1,04) \times 10^{-4}$ & 17,60 & & \\
\hline & 90 & $(22,87 \pm 0,88) \times 10^{-4}$ & 7,28 & & \\
\hline & $25 *$ & $3,35 \times 10^{-5}$ & 498,00 & & \\
\hline & $4 *$ & $5,90 \times 10^{-6}$ & 2826,94 & & \\
\hline \multirow{6}{*}{$1: 50$} & 60 & $(3,60 \pm 0,76) \times 10^{-4}$ & 49,9 & \multirow{6}{*}{62,16} & \multirow{6}{*}{0,9669} \\
\hline & 70 & $(6,53 \pm 0,60) \times 10^{-4}$ & 25,56 & & \\
\hline & 80 & $(9,76 \pm 0,64) \times 10^{-4}$ & 17,08 & & \\
\hline & 90 & $(24,76 \pm 1,83) \times 10^{-4}$ & 6,75 & & \\
\hline & $25^{*}$ & $2,41 \times 10^{-5}$ & 692,35 & & \\
\hline & $4 *$ & $3,59 \times 10^{-6}$ & 4637,81 & & \\
\hline \multirow{6}{*}{$1: 75$} & 60 & $(3,29 \pm 0,83) \times 10^{-4}$ & 51,28 & \multirow{6}{*}{65,20} & \multirow{6}{*}{0,9780} \\
\hline & 70 & $(5,65 \pm 0,88) \times 10^{-4}$ & 29,60 & & \\
\hline & 80 & $(9,81 \pm 1,31) \times 10^{-4}$ & 17,04 & & \\
\hline & 90 & $(23,69 \pm \underset{4}{0,33}) \times 10^{-}$ & 7,03 & & \\
\hline & $25 *$ & $1,88 \times 10^{-5}$ & 885,28 & & \\
\hline & $4 *$ & $2,56 \times 10^{-6}$ & 6509,71 & & \\
\hline \multirow{6}{*}{$1: 100$} & 60 & $(3,34 \pm 0,69) \times 10^{-4}$ & 46,68 & \multirow{6}{*}{61,95} & \multirow{6}{*}{0,9628} \\
\hline & 70 & $(5,34 \pm 0,55) \times 10^{-4}$ & 31,27 & & \\
\hline & 80 & $(8,89 \pm 0,53) \times 10^{-4}$ & 18,75 & & \\
\hline & 90 & $(22,24 \pm \underset{4}{0,98}) \times 10^{-}$ & 7,51 & & \\
\hline & $25 *$ & $2,17 \times 10^{-5}$ & 769,17 & & \\
\hline & $4 *$ & $3,25 \times 10^{-6}$ & 5199,77 & & \\
\hline
\end{tabular}

Keterangan:

* = data hasil pemodelan Arrhenius, bukan merupakan hasil percobaan.

Data merupkan hasil dari 3 ulangan percobaan. 
tetapan laju degradasi antosianin (k) maka semakin lambat laju degradasi antosianin. Sedangkan semakin besar nilai waktu paruh, semakin stabil. Hasil penelitian menunjukkan bahwa pada suhu $60^{\circ} \mathrm{C}$ rasio molar yang optimal adalah 1:75 dan pada suhu $70^{\circ} \mathrm{C}, 80^{\circ} \mathrm{C}$, dan $90^{\circ} \mathrm{C}$ rasio molar yang optimal adalah 1:100. Berdasarkan nilai tetapan laju degradasi antosianin (k) dan suhu dapat dihitung nilai energi aktivasi. Hasil perhitungan energi aktivasi menunjukkan bahwa rasio molar paling stabil adalah 1:75 dengan energi aktivasi sebesar 65,20 kJ/mol (Tabel 4). Semakin besar energi aktivasi menunjukan bahwa antosianin semakin stabil antosianin sebab dibutuhkan energi yang besar untuk menyebabkan antosianin mengalami degradasi (Catrien, 2009). Sehingga dapat disimpulkan bahwa antosianin yang paling stabil adalah dengan rasio molar antosianin:kopigmen 1:75.

Berdasarkan kurva energi aktivasi dapat dihitung nilai tetapan laju reaksi degradasi antosianin $(\mathrm{k})$ dan waktu paruh pada suhu $25^{\circ} \mathrm{C}$ dan $4{ }^{\circ} \mathrm{C}$. Suhu $25^{\circ} \mathrm{C}$ merupakan suhu ruang yang biasa digunakan untuk menyimpan makanan, sedangkan suhu $4{ }^{\circ} \mathrm{C}$ merupakan suhu alamari es yang digunakan untuk menyimpan makanan. Hasil penelitian ini menunjukkan bahwa kopigmen dengan rasio molar 1:75 merupakan rasio molar optimal untuk menstabilkan antosianin pada suhu $25{ }^{\circ} \mathrm{C}$ maupun $4{ }^{\circ} \mathrm{C}$ (Tabel 4). Hasil penelitian ini sejalan dengan penelitian Sari (2015) bahwa kopigmentasi antosianin Berberis crataegina dapat meningkatkan stabilitas antosianin. Rasio molar 1:100 (111,77 menit), 1:50 (93,80 menit), 1:10 (71.95 menit), memiliki nilai waktu paruh yang lebih tinggi dibandingkan rasio molar 1:0 (58,95 menit) pada suhu $90^{\circ} \mathrm{C}$. Selain itu sesuai dengan penelitian yang dilakukan oleh Kopjar and Piližota (2009) yang mengkopigmentasi antosianin Red Currant dengan asam galat. Rasio molar 1:100 (323,5 hari), 1:50 (252,9 hari), memiliki nilai waktu paruh lebih tinggi dibandingkan dengan rasio molar 1:0 (136,3 hari). Asam galat (kopigmen) melindungi antosianin dengan cara membentuk senyawa kompleks dengan antosianin yang dapat mengurangi serangan molekul air pada muatan positif kation flavilium sehingga mengurangi pembentukkan hemiketal dan kalkon yang tidak berwarna (González-Manzano dkk., 2009).

Meskipun terjadi peningkatan stabilitas termal antosianin pada saat rasio molar 1:25 sampai 1:75 namun pada saat rasio molar 1:100 terjadi penurunan stabilitas. Fenomena tersebut dapat dilihat dari nilai energi aktivasi yang lebih pada rasio molar 1:100 yang lebih rendah dibandingkan dengan rasio molar 1:75 (Tabel 3). Hasil yang sama terjadi pada penelitian Shikov dkk. (2008) dan Fischer dkk. (2013). Shikov dkk. (2008) mengkopigmentasi antosianin strawberry dengan ekstrak fenolik dari kelopak bunga mawar dengan variasi rasio molar 1:0, 1:1, 1:2, 1:3, 1:4, 1:5 pada suhu 85 ${ }^{\circ} \mathrm{C}$. Hasil penelitian menunjukkan terjadi peningkatan waktu paruh yang semula 182,4 menit (1:0) menjadi 223,6 menit
(1:1) dan 231 min (1:2). Akan tetapi pada rasio molar 1:3 mengalami penurunan waktu paruh menjadi 216,6 menit. Penurunan waktu paruh terus berlanjut hingga pada rasio molar 1:4 (216,6 menit) dan 1:5 (210 menit). Fischer dkk. (2013) melaporkan bahwa penambahan ekstrak fenolik pada Antosianin sebanyak $16 \mathrm{mg} / \mathrm{mL}$ menghasilkan nilai waktu paruh yang lebih rendah dibandingkan dengan penambahan ekstrak fenolik $10 \mathrm{mg} / \mathrm{mL}$ and $4 \mathrm{mg} / \mathrm{mL}$ pada suhu $60^{\circ} \mathrm{C}, 70$ ${ }^{\circ} \mathrm{C}, 80^{\circ} \mathrm{C}$, dan $90^{\circ} \mathrm{C}$. Fenomena tersebut mengindikasikan bahwa setiap antosianin memiliki konsentrasi optimal yang berbeda-beda. Penambahan kopigmen yang melebihi konsentrasi optimal menurunkan stabilitas termal antosianin. Menurut Fischer dkk. (2013) penurunan yang terjadi disebabkan karena konsentrasi fenolik yang ditambahkan melebihi konsentrasi mutlak antosianin.

\section{KESIMPULAN}

Dari hasil penelitian ini dapat diambil kesimpulan yaitu kopigmentasi antosianin murbei hitam dengan asam galat dapat meningkatkan stabilitas termalnya. Rasio molar antosianin:asam galat yang optimal adalah sebesar 1:75 dengan nilai energi aktivasi sebesar $65,20 \mathrm{~kJ} / \mathrm{mol}$.

\section{DAFTAR PUSTAKA}

Amin, K.A., II, H.A.H. dan Elsttar, A.H.A. (2010). Effect of food azo dyes tartrazine and carmoisine on biochemical parameters related to renal, hepatic function and oxidative stress biomarkers in young male rats. Food and Chemical Toxicology 48: 2994-2999. doi: 10.1016/j.fct.2010.07.039.

Atkins, P.W. dan Paula, J.D. (2008). Physical Chemistry. 8th ed. W.H. Freeman and Company, New York.

Bang, I.S., Yu, C.Y. dan Lim, J.D. (2010). Effects of temperature and UV irradiation on stability of anthocyanin-polyphenol copigment complex in mulberry fruits. Korean Journal Medicinal Crops Science 18(3): 191-200.

Bimpilas, A., Panagoupoulou, M., Tsimogiannis, D. dan Oreopoulou, V. (2016). Anthocyanin copigmentation and color of wine: The effect of naturally obtained hydroxycinnamic acids as cofactors. Food Chemistry 197: 39-46. doi: 10.1016/j.foodchem.2015.10.095.

Boranbayeva, T., Karadeniz, F. dan Yilmaz, E. (2014). Effect of storage on anthocyanin degradation in black mulberry juice and concentrates. Food Bioprocess 7(7): 1894-1902. doi: 10.1007/s11947-014-1296-8. 
Boulton, R. (2001). The copigmentation of anthocyanins and its role in the color of red wine: A critical review. American Journal Enologi Viticera 52(2): 67-85.

Catrien. (2009). Pengaruh Kopigmentasi Pewarna Alami Antosianin dari Rosela (Hibiscus sabdariffa L.) dengan Rosmarinic Acid terhadap Stabilitas Warna pada Model Minuman Ringan. Skripsi. Fakultas Teknologi Pertanian. Institut Pertanian Bogor. Bogor, Indonesia.

Eiro, M.J. dan Heinonen, M. (2002). Anthocyanin color behavior and stability during storage: Effect of intermolecular copigmentation. Journal Agricultural Food Chemistry 50: 7461-7466. doi: 10.1021/ jf0258306.

Fennema, R. (1996). Food Chemistry. 3th edition. Marcel Dekker, New York.

Ferreira da Silva, P., Lima, J.C., Freitas, A.A., Shimizu, K., Ma anita, A.L. dan Quina, F.H. (2005). Chargetransfer complexation as a general phenomenon in the copigmentation of anthocyanins. Journal of Physical Chemistry. A. 109: 7329-7338. doi: 10.1021/jp052106s.

Fischer, U.A., Carle, R., Kammerer, D.R. (2013). Thermal stability of anthocyanins and colourless phenolics in pomegranate (Punica granatum L.) juices and model solutions. Food Chemistry 138: 1800-1809. doi: 10.1016/j.foodchem.2012.10.072.

Gauche, C., Malagoli, E.D.S. dan Luiz, M.T.B. (2010). Effect of $\mathrm{pH}$ on the copigmentation of anthocyanins from cabernet sauvignon grape extracts with organic acids. Journal Science and Agriculture (Piracicaba, Braz). v.67. n.1. 41-46. doi: 10.1590/S0103-90162010000100006.

González-Manzano, S., Dueñas, M., Rivas-Gonzalo, J.C., Escribano-Bailón, M.T. dan Santos-Buelga, C. (2009). Studies on the copigmentation between anthocyanins and flavan-3-ols and their influence in the colour expression of red wine. Food Chemistry 114: 649-656. doi: 10.1016/j.foodchem.2008.10.002.

Hajidazeh, S. dan Jamei, R. (2015). Stability of anthocyanincopigment complex under the effect of copigment concentration in black dezfuly mulberry in sanandaj. Dalam: Second National Conference on Medicinal Plants and Sustainable Agriculture 2015. Iran.

He, J. dan Giusti, M.M. (2010). Anthocyanins: Natural Colorants with Health-Promoting Properties. Annual Review of Food Science and Technology. 1. 163-187. doi: 10.1146/annurev.food.080708.100754.

Hosseini, S., Gharachorloo, M., Ghiassi-Tarzi, B. dan Ghavami, M. (2016). Evaluation of the organic acids ability for extraction of anthocyanins and phenolic compounds from different sources and their degradation kinetics during cold storage. Polish Journal of Food and Nutrition Sciences 66(4): 261-269. doi: 10.1515/ pjfns-2015-0057.

Kara, S. dan Er elibi, E.A. (2013). Thermal degradation kinetics of anthocyanins and visual colour of Urmu mulberry (Morus nigra L.). Journal of Food Engineering 116: 541-547. doi: 10.1016/j.jfoodeng.2012.12.030.

Kokkaew, H. dan Pitirit, T. (2016). Optimization for anthocyanin and antioxidant contents and effects of acidulants on purple corn cake containing corn silk powder qualities. International Food Research Journal 23(6): 2390-2398.

Kopjar, M. dan Pilizota, V. (2009). Copigmentation effect of phenolic compounds on red currant juice anthocyanins during storage. Croatian Journal Food Science Technology 1(2): 16-20.

Lestario, L.N., Yoga, M.K. W.C. dan Kristijanto, A.I. (2014). Stabilitas antosianin jantung pisang kepok (Musa paradisiaca L) terhadap cahaya sebagai pewarna agaragar. Agritech 34(4): 374-381.

Nugraheni, M. (2014). Pewarna Alami Sumber dan Aplikasinya pada Makanan dan Kesehatan. Graha Ilmu, Yogyakarta.

Özgen, M., Ser e, S. dan Kaya, C. (2009). Phytochemical and antioxidant properties of anthocyanin-rich Morus nigra and Morus rubra fruits. Scientia Horticulturae 119: 275-279. doi: 10.1016/j.scienta.2008.08.007.

Ramadan, K.M.A. dan El-Hadidy, E.M. (2015). Color stability of anthocyanin-based extracts in nontraditional sourches: improvement of thermal stability by tannic acid. Journal Biology Chemistry Enviroment Science 10(3): 1-19.

Sari, F. (2015). The copigmentation effect of different phenolic acids on berberies crataegina anthocyanins. Journal of Food Processing and Preservation 40: 422 430. doi: 10.1111/jfpp.12619.

Shikov, V., Kammerer, D.R., Mihalev, K., Mollov, P. dan Carle, R. (2008). Heat stability of strawberry anthocyanins in model solutions containing natural copigments extracted from rose (Rosa damascena Mill.) petals. Journal of Agricultural and Food Chemistry. 56: 8521-8526. doi: 10.1021/jf801946g.

Stefănut, M.N., Cată, A., Pop, R., Moşoarcă, C. dan Zamfir, A.D. (2011). Anthocyanins HPLC-DAD and MS Characterization, total phenolics, and antioxidant activity some berries extract. Analytical Letters: 44: 2843-2855. doi: 10.1080/00032719.2011.582550. 
Suh, H.J., Noh, D.O., Kang, C.S., Kim, J.M. dan Lee, S.W. (2003). Thermal kinetics of color degradation ofmulberry fruit extract. Molecular Nutrition Food Research 47(2): 132-135. doi: 10.1002/food.200390024.

Tensiska, E., Sukarminah dan Natalia, D. (2007). Ekstraksi pewarna alami dari buah arben (Rubus idaeus Linn.) dan aplikasinya pada sistem pangan. Jurnal Teknologi dan Industri Pangan 18(1): 25-31.

Trouillas, P., Sancho-Garcia, J.C., Freitas, V.D., Gierschener, J., Otyepka, M., Dangles dan O. (2016). Stabilizing and modulating color by copigmentation: insights from theory and experiments. Chemical Reviews 116(9): 4937-4982. doi: 10.1021/acs.chemrev.5b00507.
Winarno, F.G. (1997). Kimia Pangan dan Gizi. Gramedia Pustaka Utama, Jakarta.

Zoric, Z., Dragovic-Uzelac, V., Pedisic, S., Kurtanjek, Z. Garofulic, I.E. (2014). Kinetics of the degradation of anthocyanins, phenolic acids, and flavonols during heat treatment of freeze dried sour cherry marasca pasta. Food Technology Biotechnology 52(1): 101-108. 